\title{
Reconstruction of Land Procurement Policies and Land Losses Compensation in the Name of Public Interests Based on Justice Value
}

\author{
Noor Rohmat $^{1^{*}}$, Mahmutarom ${ }^{2}$, Anis Mashdurohatun ${ }^{2}$ \\ ${ }^{1}$ Doctorate Student of Faculty of Law Sultan Agung Islamic University Semarang, Indonesia \\ ${ }^{2}$ Faculty of Law Sultan Agung Islamic University Semarang, Indonesia
}

DOI: $\underline{10.36348 / \text { sijlcj.2021.v04i02.004 }}$

| Received: 18.01.2021 | Accepted: 02.02.2021 | Published: 04.02.2021

*Corresponding author: Noor Rohmat

Abstract

In its development, the implementation of Law Number 2 of 2012 in Indonesia has not been in accordance with the mandate of Article 28D of the 1945 Constitution of the Republic of Indonesia, this can be seen in the case of land acquisition in the name of public interest for the construction of toll roads in Sido Gemah where the amount compensation is not in accordance with the expectations of the affected community. This and many other similar cases are what makes the author interested in discussing it in a study with the main problem of what weaknesses arise in the implementation of land acquisition policies and compensation for land losses for development in the name of public interest and how is the policy reconstruction based on the value of justice. The research method used in this article is a non-doctrinal method with a constructivist paradigm. Based on the research conducted, it was found that the implementation is not yet based on a justice value as seen from the unclear length of time to pay off land compensation after determining the location, unclear standards in determining the amount of compensation, and lack of transparency in the compensation process for the affected communities; As for the weaknesses in the compensation system for land acquisition for development for the benefit of Indonesia at this time, namely the weaknesses related to the laws and regulations, which both Law Number 2 of 2012 and Presidential Regulation Number 148 of 2015 do not clearly state the length of time to pay off the compensation, the amount of compensation, as well as community involvement in relation to compensation for land acquisition for development in the public interest; so it is necessary to carry out legal reconstruction both in Law Number 2 of 2012 and Presidential Regulation Number 148 of 2015 to set a better standard so that it can reflect the value of justice better.

Keywords: Reconstruction, Land Acquisition, Justice Value.

Copyright ( $\odot 2021$ The Author(s): This is an open-access article distributed under the terms of the Creative Commons Attribution 4.0 International License (CC BY-NC 4.0) which permits unrestricted use, distribution, and reproduction in any medium for non-commercial use provided the original author and source are credited.

\section{INTRODUCTION}

In 2012 the Government issued Law Number 2 of 2012 concerning Land Acquisition for Development in the name of Public Interest which is expected to guarantee the rights of both the government and the community. This law is considered to be more democratic because it is more measured in its planning, implementation, and delivery of results. Besides that, the timeframe is also prepared because each stage has a duration.

This law allows the Government to take over land to facilitate the development of new infrastructure projects. This supports investment in Indonesia because so far investors have doubts about the progress of infrastructure projects that have been implemented. Thus, this Law aims to remove the biggest obstacle to infrastructure development in Indonesia.
Law Number 2 of 2012 concerning Land Acquisition for Development in the name of Public Interest states that land must be made available for development in the name of public interest. Article 4 of Law Number 2 of 2012 stipulates that the Government guarantees the availability of land in the name of the public interest. Not only that, funding is also guaranteed by the Government, both at the central and regional levels. Article 9 paragraph (2) of Law Number 2 of 2012 also ensure that land acquisition in the name of public interest is carried out by providing appropriate and fair compensation.

As for the compensation as referred to in Law Number 2 of 2012, is appropriate and fair compensation to entitled parties in the land acquisition process. Compensation is given based on the provisions of Article 33, the appraiser's assessment of the value of 
compensation as referred to in article 32 paragraph (1) shall be carried out per plot of land, covering land above ground and underground, buildings, plants, objects related to land and other losses that can be assessed.

As for the form of compensation according to Article 36 of Law Number 2 of 2012 which can be given in the form of money, replacement land, replacement housing, stock share ownership, and other forms approved by the parties concerned.

There are four stages that must be passed in the process of land acquisition for infrastructure. First, the project planner must provide detailed location data to be used by the Provincial Government. Second, conducting public consultations. Third, determining the location. Fourth, the Ministry of ATR / BPN conducts land acquisition which is carried out by conducting assessments, deliberations to the release of the land ownership.

In the series of activities carried out by land acquisition agencies from the planning stage to the results submission stage, community involvement is an important element. In the land acquisition preparation stage, the results of the public consultation determine whether the planned location can be executed or the agency must determine another location.

Land acquisition for infrastructure projects is one of the crucial issues that determine project realization. According to the findings of the Central Java toll road team from PT. Waskita [1] the Indonesian government in 2005 offered 100 infrastructure projects for private sector development to various construction companies in the ASEAN region. However, its development has been hampered due to various land acquisition disputes, which often take up to 5 (five) years to settle. With this new law, the process of land acquisition is expected to be accelerated and can be completed in less than 9 (nine) months.

So that with the existence of Law Number 2 of 2012 regarding land acquisition, it will not take a long process, because this Law regulates the time period for taking over land in the name of public interest, which is approximately 178 (one hundred seventy-eight) working days, if the land acquisition process runs smoothly, it will take approximately 1,213 (one thousand two hundred and thirteen) working days, if there are objections from the party who owns the purchased land [2].

However, in the government's efforts regarding land acquisition, disputes between the government and the community are not uncommon. Especially in terms of not reaching an agreement regarding compensation for the affected community. In the absence of this agreement, Law Number 2 of 2012 anticipates problems that could hinder the implementation of development through consignment efforts. Consignment or compensation from the Government entrusted to the local district court is regulated in Article 42 of Law Number 2 of 2012.

Based on the various descriptions above, it appears that the state has the authority to control and carry out extensive land management. On the other hand, the need for legal protection and guarantee of legal certainty in the field of land is needed for every citizen in the form of Steady control, which means that in terms of time and/or duration a person can own and/or control the land in accordance with the authority of the said land right, and also a secure control, which means that the holder of land rights is protected from interference from fellow citizens even in the form of, for example, the authorities.

Land acquisition is an act of the government to acquire land for various development purposes, especially in the name of public interest. In principle, land acquisition is carried out by means of deliberation between parties requiring land and holders of land rights required for development activities. However, in the government's efforts to acquire land, it is not uncommon for disputes to occur between the government and the community or with the private sector.

Regarding the number of land cases that occur in the community, it is necessary to find a solution that is very beneficial for both parties. For this reason, the settlement of civil disputes relating to land outside the judiciary is ideal for land dispute resolution. Because when taken through legal channels or judicial institutions, often it does not only involve legal aspects, tenure rights, economic calculations, but it also touched the socio-cultural side. Settlement through court institutions with a more win-lose pattern often triggers prolonged non-legal conflicts. Especially if the legal issues raised only focus on one cause. The emergence of dissatisfaction with court decisions that accumulate with various aspects of land problems that have not been resolved through the courts can actually develop into physical violence. Land problems, seen from a juridical perspective alone, are no simple solutions. A concept equation is needed to create a solid and fair decision for those who ask for justice.

This problem is what urges the author to study it further in a research with the following issues:

1. What is the weakness of the implementation of land acquisition policies and land loss compensation for Development in the name of Public Interest?

2. How is the reconstruction of land acquisition policies and land loss compensation for Development in the name of Public Interest based on justice values? 


\section{METHOD OF RESEARCH}

The paradigm that is used in the research this is the paradigm of constructivism which is the antithesis of the understanding that lay observation and objectivity in finding a reality or science knowledge.[3] Paradigm also looked at the science of social as an analysis of systematic against Socially Meaningful Action through observation directly and in detail to the problem analyzed.

The research type used in writing this paper is a qualitative research. Writing aims to provide a description of a society or a certain group of people or a description of a symptom or between two or more symptoms.

Approach method used in this research is Empirical-Juridical [4], which is based on the norms of law and the theory of the existing legal enforceability of a law viewpoint as interpretation.

As for the source of research used in this study are:

1. Primary Data, is data obtained from information and information from respondents directly obtained through interviews and literature studies.

2. Secondary Data, is an indirect source that is able to provide additional and reinforcement of research data. Sources of secondary data in the form of: Primary Legal Material and Secondary Legal Materials and Tertiary Legal Material.

In this study, the author use data collection techniques, namely literature study, interviews and documentation where the researcher is a key instrument that is the researcher himself who plans, collects, and interprets the data.[5] Qualitative data analysis is the process of searching for, and systematically compiling data obtained from interviews, field notes and documentation by organizing data into categories, describing it into units, synthesizing, compiling into patterns, selecting important names and what will be studied and make conclusions.

\section{RESEARCH RESULT AND DISCUSSION Weakness of The Implementation of Land Acquisition Policies And Land Loss Compensation For Development In The Name Of Public Interest}

Basically, compensation for losses arising from land acquisition for the construction of the Semarang-Batang toll road must be based on Article 33 paragraph 3 of the 1945 Constitution of the Republic of Indonesia which states that "the earth, water and the wealth contained therein are controlled by the state and used for the greatest prosperity of the people. "

Furthermore, the implementation of compensation arising from land acquisition for the construction of the Semarang-Batang toll road for example [6], must also be in accordance with Article 18 of the UUPA which states that: For the public interest, including the interests of the nation and the state as well as the common interests of the people, land rights can be revoked, by providing appropriate compensation and in a manner regulated by law so that it is clear that the implementation of compensation arising from the land acquisition is clear. the construction of the SemarangBatang toll road must also be in line with the Fifth Precepts of Pancasila and that is social justice for all the people of Indonesia.

In its development, the implementation of compensation arising from land acquisition for the construction of the Semarang-Batang toll road is regulated in Law Number 2 of 2012 which is later technically regulated in Presidential Regulation Number 71 of 2012 jo. Presidential Regulation Number 99 of 2014 jo. Presidential Regulation Number 30 of 2015 jo. Presidential Regulation Number 148 of 2015, that uses a consignment system entrusted to the court which is carried out in the absence or by prior negotiation with the relevant community. It is clear that this will be distracted by the government by executing and determining compensation unilaterally and in an authoritarian manner. This also clearly contradicts Pancasila, the 1945 Constitution of the Republic of Indonesia, and the UUPA.

The consignment itself is basically not only regulated in Law Number 2 of 2012 and Presidential Decree Number 71 of 2012 Presidential Regulation Number 71 of 2012 jo. Presidential Regulation Number 99 Year 2014 jo. Presidential Regulation Number 30 of 2015 jo. Presidential Regulation Number 148 of 2015, The compensation system is also known in the Civil Code as stipulated in Article 1239 and Article 1243 of the Civil Code which states that compensation includes compensation in terms of costs, losses, and interest. However, there are differences in the implementation of the consignment between Law Number 2 of 2012 and Perpres Number 71 of 2012 Presidential Regulation Number 71 of 2012 jo. Presidential Regulation Number 99 Year 2014 jo. Presidential Regulation Number 30 of 2015 jo. Presidential Regulation Number 148 of 2015 with a consignment in the Civil Code. Consignment in the Civil Code can only be carried out if there has been prior negotiation between the parties so that there is a legal relationship. This can be seen in Articles 14041412 of the Civil Code. Article 1404 of the Civil Code states that if the debtor refuses payment, then the debtor can make an offer of cash payment of what is owed, and if the debtor refuses, they can deposit the money or goods to the court. Such an offer, followed by safekeeping, can only be accepted as a form of payment, if the offer has been made according to the law while what is deposited in this manner remains in the account of the debtor.

Furthermore, Article 17 paragraph (2) Keppres No.55 of the Year 1993 states that in the case of land, buildings, plants, or objects related to land that is jointly 
owned by several people, one or several of them cannot be found, then the compensation which is the right of the person who cannot be found is consigned to the local district court by the government agency requiring the land. The consignment known in Keppres No.55 of the 1993 is only for the purpose of delivering the agreed compensation, but the person concerned was not found.

Based on the scope of Keppres No.55 of the 1993, it is clear that this land acquisition regulation only applies to land acquisition conducted by government agencies for public purposes. Therefore consignment can only be applied to compensation payments for land acquisition carried out by Government Agencies in the name of public interest, provided that there is indeed an agreement between the two parties who need land and the holder of land rights and the owner of buildings, plants and/ or objects that are on or below the ground.

Regarding the land acquisition in the name of public interest, there has not been found uniformity in the opinion of both academics and practitioners on whether consignment can be applied in the release or transfer of rights (formerly known as land acquisition by Government Agencies) or not, as for land acquisition carried out by the private sector, all scholars agreed that consignment is not applicable to it.

The Supreme Court of the Republic of Indonesia also confirmed through its decision Reg. No. 3757 PK / Pdt / 1991 dated 6 August 1991 which stated that consignment could not be applied in land acquisition conducted by the government. Consignment is only known or regulated in the Civil Code and Presidential Decree No.55 / 1993 concerning Land Acquisition for the Implementation of Development for Public Interest which has now been declared invalid based on Presidential Regulation Number 36 of 2005 concerning Land Acquisition for the Implementation of Development for Public Interest as Amended by Presidential Regulation Number 65 of 2006 concerning Amendments to Presidential Regulation Number 36 of 2005 concerning Land Acquisition for Implementation of Development for Public Interest.

Then on May 21, 2007, the Head of BPN (National's Land Office) Regulation No 3/2007 was issued concerning Provisions for the Implementation of Presidential Decree (Perpres) No. 36/2005 which was amended by Perpres No 65/2006 concerning Amendments to Perpres No. 36/2005. Broadly speaking, the important points in the Head of BPN Regulation No. 3/2007 relating to consignment are the land price appraisal by the Land Price Appraisal Team based on NJOP (Tax Object Selling Value) or real value by taking into account the current year's NJOP and can be guided by 6 (six) variables, namely location, land's location, land's status, land's designation, the suitability of land use with its permit, facilities and infrastructure, and other factors. The assessment of the price of buildings and/ or plants and/ or other objects is carried out by the relevant agencies. The results of the assessment are submitted to P2T to be used as a basis for deliberation.

The provisions for deliberation are regulated in Articles 31-38, the agreement is deemed to have been reached when 75 percent of the land area has been obtained or 75 percent of the owners have agreed on the form and amount of compensation. If the deliberation does not reach 75 percent, then there can only be 2 (two) possibilities, namely:

a) If the location can be moved, the P2T must propose to the government agencies that they need new land to move the location;

b) If the location cannot be moved (according to the criteria in Article 39), then the land acquisition activities will continue. If 25 percent of the owners have not agreed on the form and amount of compensation or 25 percent of the land area has not been obtained, P2T shall conduct further deliberations within 120 calendar days.

It was further clearly explained that if the 120 day period had passed, then For those who have agreed on the form and amount of compensation, the compensation shall be submitted with an Official Report on the Delivery of Compensation or an Official Report on the Offer for Compensation. For those who still refuse, the government agency will deposit compensation at the local District Court (PN) based on the Official Report on the Delivery of Compensation.

The Regency/ Municipal of P2T shall produce an Official Report on the Results of the Deliberation and Determination of the form and/ or the amount of compensation signed by all P2T members, government agencies that require the land, and their owners. P2T decisions regarding the form and/ or amount of compensation are regulated in Articles 40-42. Owners who object to the P2T decision can submit objections along with the reasons thereof to the Regent/ City/ Governor/ Minister of Home Affairs within a maximum period of 14 (fourteen) days. The Decision on the settlement of objections shall be issued within a maximum period of 30 (thirty) days. If the owners continue to object and the construction site cannot be moved, the Regent/ Mayor/ Governor/ Minister of Home Affairs proposes to revoke land rights according to Law No. 20/1961. With regard to the payment of compensation, the provisions of Article 43-47 regulate those who are entitled to receive compensation are:

a) Land rights holders;

b) Nazir of a waqf land;

c) Land compensation for HGB/ HP/HPL holders;

d) Compensation for buildings and/ or plants and/ or objects on the HGB/ HP land given over the HGB/ HPL land is given to the owner of the building and/ or plants and/ or objects. 
Compensation in the form of money is given in not later than 60 (sixty) days from the date of the decision. For compensation that is not in the form of money, the delivery shall be made within a period agreed by the parties that can be in the form of:

a) Replacement land and/ or building or resettlement;

b) Land and/ or buildings and/ or other facilities with a value at least equal to the waqf property released;

c) Recognition is in the form of construction of public facilities or other forms of benefit to the welfare of the local community (for ulayat land), or according to the decision of the competent official for land by government agencies or local governments.

Furthermore, the custody of compensation for certain causes (Article 48), namely:

a) To whom is entitled to compensation where it is not known of their whereabouts

b) Land, buildings, plants, and or other objects related to land are the object of a court case;

c) Ownership disputes that are still ongoing and have not yet been resolved;

d) Land, buildings, plants, and other objects related to land are being put in place by the competent authority;

e) Custody of compensation is carried out by requesting custody of the Head of the District Court.

In regard to compensation, The Presidential Decree and Head of BPN Regulation No 3/2007 does not give any further details as it is a separate process that requires attention on various matters, including that the selection of a resettlement location must be the result of deliberations with the party to be moved by involving the receiving community; The location of relocation must be equipped with public facilities and infrastructure. Such infrastructure and facilities must also be utilized by the local community. Likewise, the Perpres does not mention compensation for nonphysical factors in the form of income restoration efforts.

In its development with the Presidential Decree Number 71 of 2012 Presidential Regulation Number 71 of 2012 jo. Presidential Regulation Number 99 of the Year 2014 jo. Presidential Regulation Number 30 of 2015 jo. Presidential Regulation Number 148 of 2015 consignment is often carried out without prior consultation with the public. It is precisely at this point that injustice occurs, especially for the community where the determination of the amount of the consignment and the mechanism for implementing the consignment are determined unilaterally by the government.

Nawiasky [7] in his theory states that apart from layered and tiered law, legal norms are also grouped, and the grouping of legal norms in a country consists of four major groups, namely: a) Staatsfundamentalnorm (State Fundamental Norms);

b) Staatsgrundgesetz (Basic Country Rules / Basic Country Rules);

c) Formell Gezets (Formal Legislation);

d) Verordnung \& Autonome Satzung (Implementing Rules \& Autonomous Rules).

Based on the description above, it can be understood that legal norms are arranged in stages and layers, as well as in groups, showing a legal political line. This is because the basic norms containing social ideals and ethical judgments of society are translated and concretized into lower legal norms.

This shows that there are a demand from the community, both social ideals and ethical judgments, to be realized in social life through created legal norms. The hierarchical and multi-layered legal norms also indicate a synchronization line between higher legal norms and lower legal norms. This is because lower legal norms are applicable, sourced, based, and therefore should not conflict with higher legal norms.

When looking at Nawiasky's theory above, it is clear that Law Number 2 of 2012 is Formell Gezets and Presidential Regulation Number 71 of 2012 jo. Presidential Regulation Number 99 of the Year 2014 jo. Presidential Regulation Number 30 of 2015 jo. Presidential Regulation Number 148 of 2015 as Verordnung \& Autonome Satzung is in conflict with Article 1 paragraph (2) and Article 18 of UUPA Number 5 of 1960 Formell Gezets, as Article 28D and Article 33 paragraph (3) of the 1945 NRI Constitution as Staatsgrundgesetz, which are also clearly contradicts the Fourth Paragraph of the Preamble of the 1945 Constitution of the Republic of Indonesia and Pancasila which are the fundamental norms So that in the case of consignment implementation issues as referred to in Law Number 2 of 2012 and Presidential Decree Number 71 of 2012 Presidential Regulation Number 71 of 2012 jo. Presidential Regulation Number 99 of the Year 2014 jo. Presidential Regulation Number 30 of 2015 jo. Presidential Regulation Number 148 of 2015 happens, there is a gap of regulation where the government are able to dominate the community in determining the implementation of the continuation, including the construction of the Semarang-Bawen toll road, which will result in opportunities for discrimination against the community in terms of land compensation. Based on the existing problems, it is clear that there has been a harmonization and desynchronization of legal politics related to compensation due to land acquisition for state development.

So that with the opportunity to create an authoritarian consignment system from the existence of Article 42 of Law Number 2 of 2015 and Article 73 of Presidential Decree Number 71 of 2012 Presidential 
Regulation Number 71 of 2012 jo. Presidential Regulation Number 99 of the Year 2014 jo. Presidential Regulation Number 30 of 2015 jo. Presidential Regulation Number 148 of 2015 means that the concept of consignment or compensation for existing land will deviate far from the state's objective which is none other than realizing the welfare of the community.

This has never been given sufficient concern by the government as even in 2020, where a Presidential Regulation Number 66 of 2020 concerning Funding for Land Acquisition for Development for Public Interest in the Context of Implementing National Strategic Projects was made. The Presidential Regulation Number 66 of 2020 still does not clearly regulate the amount of compensation and regarding the regulation of community involvement in calculating the amount of land acquisition and compensation for the development in the name of public interests.

In line with the theory of welfare and state responsibility from J.M. Keynes in Marzuki [8], a state must actively strive for prosperity, act fairly that can be felt by all people equally and equally, not for the welfare of certain groups, but for all people. It is very careless if economic development is neglected and economic growth is only viewed and concentrated on mere percentage figures.

People's welfare is a real indicator of a nation's prosperity. This is in line with Cicero, that good governance is a government based on civil society, where civil society is a manifestation of community life based on religious, moral, ethical and cultural values.

\section{Reconstruction of Land Acquisition Policies and Land Loss Compensation for Development In The Name Of Public Interest Based On Justice Values}

Before discussing legal reconstruction in the implementation of land acquisition and compensation for development in the name of public interest based on the value of justice, it is necessary to first understand the elements related to law enforcement.

In relation to this, Chambliss and Seidman in Warassih [9] stated that any action that will be taken by the stakeholders, implementing agencies, and legislators is always within the scope of the complexity of social, cultural, economic, and political forces and so on. All social forces always work to make regulations function, sanctions, and all activities of implementing institutions are applicable. Finally, the role played by these legal institutions and institutions is the result of the operation of various factors where In its development, which often results in large-scale population movements requires planning related to the development of a mature urban concept. This includes the area where the community has moved, which is affected by urban expansion and development, which often changes the function of land, especially land rights from private rights to land used for the development of public spaces. Therefore, the guidance, assistance, and participation of the government in ensuring the welfare of the community after moving and starting a new life in a new settlement with the development of economic and socio-cultural potential can be realized evenly to realize social justice for all [10].

In order to make this happen, it is necessary to carry out legal reconstruction both in Law Number 2 of 2012 and Presidential Regulation Number 148 of 2015. In law Number 2 of the year 2012, the amended provision is for Article 34 so that the provisions become

a) Value of Compensation as assessed by the Appraiser as referred to in Article 33 is the value at the time the announcement of the determination of the construction location for Public Interest as referred to in Article 26.

b) The amount of Compensation value based on the Appraiser's assessment as referred to in paragraph (1) shall be submitted to the Land Agency with an official report.

c) The value of compensation based on the results of the appraiser's assessment as referred to in paragraph (2) shall be the basis for deliberation to determine the compensation.

The government is obliged to pay compensation for land affected by land acquisition for development in the name of public interest, no later than six months after the location determination is made. Then the provisions that need to be amended further, namely Article 121 paragraph (4) Presidential Regulation Number 148 of 2015 which then becomes "land appraisal in the framework of land acquisition as referred to in paragraph (1), where agencies requiring the land-use appraisal services must also considering the results of the deliberations with affected communities".

Then the last is the provisions in Article 11 of Presidential Regulation Number 148 of 2015 so that the provisions of Article 11 of Presidential Regulation Number 148 of 2015 must be changed so that the notification of development plans as referred to in paragraph (1) which contains information must contain:

a) The purpose and objectives of the development plan;

b) Location of land and land area required;

c) Stages of land acquisition plan;

d) Estimated period of land acquisition implementation;

e) Estimated period of development implementation;

f) Information on the procedure for calculating the amount of compensation; and

g) The amount of compensation determined by the government as a whole. 


\section{CONCLUSION}

1. The Weaknesses in the compensation system in land acquisition for development for the benefit of Indonesia currently are found in its laws, that is Law Number 2 of 2012 and Presidential Regulation Number 148 of 2015 which does not clearly state the length of time to pay off the compensation, the amount of compensation, as well as community involvement related to compensation for land acquisition for development in the public interest.

2. Legal reconstruction as referred to is in Law Number 2 of 2012 and Presidential Regulation Number 148 of 2015 is needed where In Law Number 2 of 2012, the provision is Article 34 is changed into 1) Compensation Value as assessed by the Appraiser as referred to in Article 33 is the value at the time the announcement of the determination of the construction location for Public Interest as referred to in Article 26. 2) The amount of compensation value based on the Appraiser's assessment as referred to in paragraph (1) shall be submitted to the Land Agency with an official report. 3) The value of compensation based on the results of the Appraiser's assessment as referred to in paragraph (2) shall be the basis for deliberation to determine the compensation.

\section{REFERENCES}

1. Ramlan, A., Gunarto, B., \& Minn, D. (2019). Reconstruction of the Legal Protection of Land Rights Holders In Land Procurement In The
Public Interest Based On The Value Of Pancasila Justice. International Journal of Advanced Research. 7:147-159.

2. Langelo, R. (2018). Legal Impact of Land Acquisition for Public Land Procurement Development. Tadulako Master Law Journal. 2. 59. 10.22487/j25797697.2018.v2.i2.10410.

3. Faisal. (2010). Menerobos Positivisme Hukum, Rangkang Education, Yogyakarta.

4. Johnny, I. (2005). Teori dan Metodologi Penelitian Hukum Normatif, Bayumedia, Surabaya.

5. Moleong, L. (2002). Metode Penelitian Kualitatif, PT Remaja Rosdakarya, Bandung.

6. Kotalewala, F., Laturette, A., \& Uktolseja, N. (2020). Penyelesaian Sengketa dalam Pengadaan Tanah Bagi Pembangunan Jalan untuk Kepentingan Umum. SASI. 26. 415 10.47268/sasi.v26i3.397.

7. Hans, N. (1948). Allgemeine Rechtslehre als System der rechtlichen Grundbegriffe, $2^{\text {nd }}$ Edition, Einseideln / Zurich / Koln, Benziger.

8. Peter, M. M. (2008). Pengantar Ilmu Hukum, Kencana, Jakarta.

9. Esmi, W. (2011). Pranata Hukum Sebuah Telaah Sosiologis, UNDIP Press, Semarang.

10. Widodo, W., Budoyo, S., \& Pratama, T. G. W. (2018). The role of law politics on creating good governance and clean governance for a freecorruption Indonesia in 2030. The Social Sciences, 13(8), 1307-1311. 